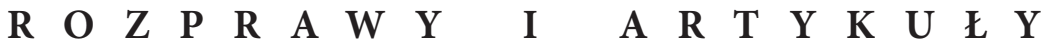

ks. Ginter Dzierżon

Ius Matrimoniale

28 (2017) $\mathrm{nr} 2$

Wydział Prawa Kanonicznego UKSW

\section{Zmiany zapisów kanonów w obszarze materialnego prawa małżeńskiego na mocy motu proprio „De concordia inter Codices”}

W dniu 31 maja 2016 r. papież Franciszek wydał motu proprio „De concordia inter Codices”, na mocy którego zostały zmienione brzmienia niektórych kanonów obowiązującego Kodeksu Prawa Kanonicznego ${ }^{1}$. Jak pisze autor dokumentu we „Wprowadzeniu”, głównym celem opublikowanego aktu prawnego jest harmonizacja zapisów normatywnych występujących w Kodeksie Prawa Kanonicznego z 1983 r. oraz w Kodeksie Kanonów Wschodnich z 1990 r.

$\mathrm{W}$ niniejszym opracowaniu przedmiotem uwagi nie staną się wszystkie dokonane modyfikacje, ale wyłącznie te, które zostały wprowadzone $\mathrm{w}$ obszarze materialnego prawa małżeńskiego. Ze wstępnej lektury papieskiego dokumentu wynika, iż punktem wyjścia do dokonania zmian stała się niejednoznaczność zapisu kan. $1127 \$ 1$ KPK, dotyczącego warunków asystowania przy zawieraniu małżeństwa przez katolików ze stroną niekatolicką obrządku wschodniego.

\section{Niejednoznaczność zapisu kan. 1127 \$ 1 KPK}

Prawodawca w kan. $1127 \$ 1 \mathrm{KPK}$ co do formy wprowadził odmienne ustalenia w odniesieniu do małżeństw mieszanych zawieranych przez

\footnotetext{
1 Franciscus, Motu proprio De Concordia inter Codices, 31.05.2016, https//:www. vatican.va/content/Francesco/it/motu_proprio/documents/papa-francesco-motu-proprio-_20160531_de-concordia-inter-codices.htlm [dostęp: 6.10.2016], (dalej: DCIC).
} 
katolików łacińskich z akatolikami obrządku wschodniego oraz z innymi ochrzczonymi akatolikami. W związkach z wiernymi obrządku wschodniego forma kanoniczna jest wymagana jedynie do godziwości; udział świętego szafarza natomiast jest obligatoryjny do ważności.

W interpretacji kan. $1127 \$ 1$ KPK nie występuje zgodność opinii pomiędzy komentatorami łacińskimi a wschodnimi w kwestii tego, kto może pełnić funkcję świętego szafarza. Pierwsi z nich wyjaśniając ten problem, biorąc pod uwagę dyspozycję kan. $1108 \$ 1$ KPK nie wykluczają, iż małżeństwo w konfiguracji, o której traktuje kan. $1127 \$ 1$ KPK mogłoby być również zawierane przed diakonem ${ }^{2}$; co więcej, nieliczni autorzy opowiadają się nawet za możliwością delegacji władzy w warunkach zwyczajnych wiernemu świeckiemu ${ }^{3}$, na co kategorycznie nie ma przyzwolenia w doktrynie wschodniej, ponieważ uwydatnia się w niej w sposób szczególny konieczność błogosławienia małżeństwa przez kapłana ${ }^{4}$. Tłumacząc tę kwestię Joseph Prader skonstatował, iż w prawie wschodnim nie do pomyślenia jest sytuacja, iż małżeństwo mogłoby być celebrowane bez obecności ordynariusza miejsca lub proboszcza ${ }^{5}$.

Występująca w doktrynie niezgodność poglądów kanonistów sprawiła, że prawodawca w art. 11 DCIC w miejsce zwrotu ,interventus ministri sacri” zdecydował się wprowadzić zwrot „l'intervento di un sacerdote”. Analizując ten zapis najpierw pragnę spostrzec, iż

2 Por. F. Bersini, Il diritto canonico matrimoniale, Torino 1994, s. 187; J. J. García FAílde, La nulidad matrimonial, hoy, Salamanca 1999, s. 334; R. Althaus, J. PrADER, J. F. REINHARD, Das kirchliche Eherecht in der seelsorgische Praxis, Essen 2013, s. 161. Szerzej na ten temat zob. T. JAKUBIAK, Początki prawa regulujacego możliwość asystowania diakona przy zawarciu małżeństwa $w$ zwykłych warunkach, Studia Bobolanum 3 (2015), s. 171-187.

3 Por. V. PospishiL, Estern Catholic Marriage Law, Broklyn 1991, s. 372.

4 Por. K. Nitkiewicz, Katolickie Kościoły Wschodnie, Sandomierz 2014, s. 8990; N. DurÂ, T. Petrescu, Institution of the Family according the Taeching of the Orthodox Church, Ecumeny and Law 2 (2104), s. 120.

5 Por. J. Prader, La forma del celebrazione del matrimonio, w: Il matrimonio nel Codice dei Canoni delle Chiese Orientali, Città del Vaticano 1994, s. 298; G. KADZIOCH, Il ministro del sacramento del matrimonio nella tradizione e nel diritto canonico latino e orientale, Roma 1997, s. 219. 
łacińskie słowo „interventus” przez tłumacza polskiego zostało przetłumaczone jako „udział”. W moim przekonaniu, ten polski termin nie oddaje jednak w pełni myśli ustawodawcy. Według „Słownika języka polskiego" jednym ze znaczeń słowa „udział” jest „uczestnictwo w czymś" , natomiast jednym z desygnatów normatywnego terminu „interventus” jest „orędownictwo, wstawiennictwo”" To ostatnie znaczenie ma wymiar dynamiczny, nie zaś pasywny. Dlatego też włoskie wyrażenie „l'intervento di un sacerdote” należałoby przetłumaczyć w sensie „interwencja kapłana”.

Wprowadzona w art. 11 DCIC modyfikacja treści kan. $1127 \$ 1 \mathrm{KPK}$ kończy więc spór doktrynalny dotyczący podmiotu uprawnionego do błogosławieństwa w konfiguracji określonej w kan. $1127 \$ 1$ KPK. Pośrednio kończy także spór w kwestii ważności tego typu małżeństw. Związków zatem z wiernymi wschodnimi, o których traktuje kan. $1127 \$ 1$ KPK obecnie nie może błogosławić diakon. Modyfikacja treści tego kanonu spełnia więc postulaty wyrażone w n. 18 soborowego „Dekretu o ekumenizmie” oraz w trakcie prac kodyfikacyjnych ${ }^{8}$, aby poprzez wprowadzenie odpowiednich rozwiązań unikać nieważności zawieranych małżeństw mieszanych ${ }^{9}$.

Komentując art. 11 DCIC pragnę również spostrzec, iż ustawodawca w legislacji łacińskiej nie posłużył się terminem „benedictio”

6 Por. Udział, w: L. Drabik, A. Kubiak-Sokó£, E. Sobol, L. Wiśniakowska (red.) Słownik języka polskiego, Warszawa 2014, s. 1080.

7 Por. Interventus, w: A. Jougan, Słownik kościelny łacińsko-polski, Warszawa 1992, s. 355; Interventus, w: J. Sondel, Słownik łacińsko-polski dla prawników i historyków, Kraków 1997, s. 519.

8 Por. Pontificia Commissio Codici Iuris Canonici Recognoscendo, Relatio complectens synthesim animadversionum ab. Em.mis Patribus Commisionis ad novissimum Schema Codicis Iuris Canonici exhibatarum, cum responsionibus a Secretaria et Consultoribus datis, Typis Polyglotis Vaticanis 1981, s. 261; M. OrTIz, La supplenza della facoltà per assistere al matrimonio e la funzione della forma al servizio dello ius connubii, w: H. Franceschi, M. Ortiz (red.), Ius et matrimonium, Roma 2015, s. 46.

9 Por. J. Fornés, La forma en el matrimonio de un católico con acatólico, w: R. Rodríguez-Ocaña Forma jurídica y matrimonio canónico, Pamplona 1998, s. 77; F. Aznar Gil, Derecho matrimonial canónico, t. 3, Salamanca 2003, s. 99. 
funkcjonującym w legislacji wschodniej; pozostał przy terminie „interventus”, aby tym sposobem nie zatrzeć różnic doktrynalnych występujących pomiędzy tradycją łacińską oraz tradycją wschodnią w tej materii.

\section{Następstwa zamiany zapisu kan. $1127 \$ 1$ KPK}

Wprowadzenie zmian w kan. $1127 \$ 1 \mathrm{KPK}$ z natury rzeczy wymusiło kolejne zmiany w treści kilku innych kanonów dotyczących kanonicznej formy zawarcia małżeństwa. W DCIC zmodyfikowano zapisy kan. 1108 (art. 6), kan. 1111 KPK (art. 8) oraz kan. 1112 KPK (art. 9). Przy tym trzeba podkreślić, iż znaczenie kluczowe w tym wypadku ma wprowadzenie w art. 6 DCIC nowego paragrafu trzeciego, który wszedł w skład struktury kan. 1108 KPK.

\subsection{Kapłan asystującym przy zawieraniu małżeństwa mieszanego (art. 6 DCIC)}

Jak już nadmieniono, prawodawca w art. 6 DCIC zmienił zapis kan. 1108 KPK dodając $\$ 3$ o następującym brzmieniu: „Tylko kapłan asystuje ważnie przy zawieraniu małżeństwa dwóch stron wschodnich lub małżeństwa zawieranego pomiędzy stroną katolicką łacińską i katolicką wschodnią lub niekatolicką wschodnią".

Prezentując tę kwestię w pierwszym rzędzie należy stwierdzić, iż modyfikacja, o której mowa, pozostaje w związku z tą, którą wprowadzono w treści art. 11 DCIC. Wiąże się ona $\mathrm{z}$ funkcjonującą w tradycji Kościołów Wschodnich instytucją rytu świętego. Z badań przeprowadzonych przez J. Pradera wynika, iż od VIII w. na Wschodzie istniał wymóg rytu liturgicznego. W XII wieku pod wpływem głównie poglądów teologów greckich ukształtowała się doktryna, zgodnie z którą istota sakramentu małżeństwa wyraża się w błogosławieństwie kapłańskim. Kapłan jest więc szafarzem sakramentu małżeństwa ${ }^{10}$.

10 Por. J. Prader, La forma del celebrazione del matrimonio, dz. cyt., s. 286. 
Należy dodać, iż obecnie wymóg konieczności świętego obrzędu w Kościołach Wschodnich wynika z założenia, że przepisy o formie kanonicznej pozostają w ścisłym związku z przepisami o formie liturgicznej. Ta ostatnia bowiem w warunkach zwyczajnych jest obligatoryjna ${ }^{11}$. Istotnym komponentem formy liturgicznej jest obrzęd ukoronowania $^{12}$. Poruszając ten problem Marek Lewreszuk mówi nawet o sakramencie ukoronowania ${ }^{13}$. Jak pisze Grzegorz Kadzioch, w księgach liturgicznych obrzęd ten jest uznawany za element istotny sakramentu małżeństwa. Autor ten wykazał, że od czasów wczesnochrześcijańskich był on sprawowany w czasie Eucharystii, dlatego też konieczny był udział kapłana ${ }^{14}$. Według Kadziocha, ryt święty nie jest obrzędem pozostającym w relacji zewnętrznej do formy kanonicznej, ale jest elementem istotnym sakramentalności, wynikającym z woli Kościoła. Kapłan bowiem w tym porządku prawnym jest szafarzem sakramentu małżeństwa łącznie $\mathrm{z}$ nupturientami ${ }^{15}$.

W legislacji wschodniej wymóg nieodzowności błogosławieństwa kapłana został skodyfikowany w kan. $828 \$ 1$ KKKW o następujących brzmieniu: „Tylko te małżeństwa są ważne, które są zawierane z zachowaniem świętego obrzędu wobec Hierarchy miejsca lub proboszcza miejsca lub kapłana, który od jednego z nich otrzymał upoważnienie do błogosławienia małżeństw [...]"16.

11 Por. G. KAdzIOCH, Il ministro del sacramento del matrimonio nella tradizione e nel diritto canonico latino e orientale, dz. cyt., s. 222.

12 Szerzej na temat tego obrzędu zob. J. Meyendorf, Mał̇̇eństwo w prawosławiu. Liturgia, teologia, życie, Lublin 1995, s. 41-50. Autor ten pisze, iż według doktryny wschodniej obrzęd ten powinien zostać także zachowany podczas zawierania małżeństw mieszanych.

13 Por. M. Lewreszuk, Sakrament małżeństwa. Liturgiczna symbolika i znaczenie sakramentu małżéstwa w Kościele prawosławnym, Białystok 2014, s. 45-116.

14 Por. G. KadzIOCH, Il ministro del sacramento del matrimonio nella tradizione e nel diritto canonico latino e orientale, dz. cyt., s. 222.

15 Tamże, s. 236.

16 Szerzej na temat znaczenia świętego rytu w Kościole prawosławnym zob. J. STOJANOvic, Interkonfessionelle Ehen. Die kirchenrechtliche und pastorale Praxis der Orthodoxen Kirche, München 2013, s. 56. 
Interpretując ten kanon komentatorzy podkreślają, że uprawnionymi do błogosławienia małżeństwa są jedynie prezbiterzy oraz biskupi; takich uprawnień nie posiadają natomiast diakoni ${ }^{17}$. Wyjaśniając ten problem Prader skonstatował, iż ze źródeł kanonicznych wynika, że w żadnym z Kościołów Wschodnich małżeństwo nie jest błogosławione przez diakona ${ }^{18}$. Zasada, o której mowa została uwydatniona w kilku kanonach KKKW (kan. $302 \$ 2,789,828, \S 1-2,832$, $834 \$ 2,839,840 \$ 1,841 \$ 1$ i 3$)^{19}$. W prawie wschodnim kompetentny autorytet nie może delegować zatem władzy do błogosławienia małżeństw diakonowi ${ }^{20}$, a tym bardziej wiernemu świeckiemu ${ }^{21}$.

Kontynuując te rozważania należy dodać, iż w KKKW pojęcie „święty obrzęd” został określony w kan. 828 \$ 2 KKKW następująco: „Za święty uważany jest obrzęd z udziałem kapłana asystującego i błogosławiącego". Z zapisem tym nie do końca koresponduje brzmienie kan. $1108 \$ 2$ KPK w którym stwierdzono: „Za asystującego przy zawieraniu małżeństwa uważa się tylko tego, kto jest obecny i pyta nowożeńców, czy wyrażają zgodę i przyjmują ją w imieniu Kościoła"22. Przy tym należy zauważyć, iż taki zapis interpretowany literalnie łącznie z paragrafem pierwszym tego kanonu nie wyklucza możliwości asystowania przy zawieraniu małżeństwa - również w odniesieniu do małżeństw mieszanych zawieranych przez wiernych wschodnich przez diakona ${ }^{23}$. Stąd też wielu kanonistów uważa, iż diakon łaciński

17 Por. H. Alwan, Commento al can. 828 CCEO, w: P. V. Pinto (red.) Commento al Codice dei Canoni delle Chiese Orientali, Città del Vaticano 2001, s. 707-708; G. KadzIoch, Il ministro del sacramento del matrimonio nella tradizione e nel diritto canonico latino e orientale, dz. cyt., s. 219-220.

18 Por. J. Prader, Il matrimonio in Oriente e in Occidente, Rome 2003, s. 226.

19 Por. J. Prader, La forma del celebrazione del matrimonio, dz. cyt., s. 298.

20 Tamże.

21 Por. G. Kadzioch, Il ministro del sacramento del matrimonio nella tradizione e nel diritto canonico latino e orientale, dz. cyt., s. 222.

22 Zob. Zestawienie kanonów $1108 \mathrm{KPK}$ i $828 \mathrm{KKKW}$ w: A. D’AUrIA, Il matrimonio canonico nell'ordine della natura e della grazia, Roma 2016, s. 302.

23 Szerzej na ten temat zob. T. JAкUBIAK, Diakon świadkiem urzędowym zawarcia małżenstwa w zwykłych warunkach według prawa obowiązującego od promulgacji Kodeksu z 1983 r., Ius Matrimoniale 1 (2016), s. 45-74. 
mógłby zostać delegowany do błogosławienia małżeństw zawieranych przez katolików wschodnich ${ }^{24}$.

Brak zgodności interpretacyjnej w kwestii szafarza sakramentu małżeństwa zawieranego pomiędzy katolikami łacińskimi oraz katolikami lub akatolikami wschodnimi sprawił, iż prawodawca w art. 6 DICIC zdecydował się na rozwiązanie, zgodnie z którym w takiej hipotezie asystującym może być wyłącznie kapłan, to znaczy prezbiter lub biskup.

\subsection{Zmiany wprowadzone $w$ innych kanonach (art. 8 i 9 DCIC)}

Dalszym następstwem zmian wprowadzonych w zapisie kan. 1127 $\$ 1$ KPK są modyfikacje brzmienia dwóch innych kanonów z obszaru przepisów o formie kanonicznej, jakimi są kan. 1111 i 1112 KPK. W paragrafach pierwszych obu regulacji pojawiła się bowiem identyczna klauzula „Z zachowaniem tego co zostało nakazane w kan. $1108 \$ 3$ KPK” ( fermo restando quanto disposto dal can. 1108 \& 3 CIC). Oznacza to zatem, iż kompetentny autorytet w przypadku zawierania małżeństw w konfiguracji, o której tratuje DCIC, nie może delegować władzy ani diakonowi, a tym bardziej osobie świeckiej.

\section{Zmiany w zapisie kan. 1109 KPK (art. 7 DCIC)}

Nieco inny charakter mają modyfikacje występujące w art. 7 DCIC dotyczącym treści kan. 1109 KPK odnoszącego się do zakresu władzy ordynariusza miejsca i proboszcza. Prawodawca w art. 7 DCIC zrezygnował ze zwrotu „sit ritus latini ” obecnego w kan. 1109 KPK, wprowadzając w to miejsce zwrot „sia ascritta alla Chiesa latina”.

Pojęcie "ryt” w sensie obrządku zostało zdefiniowane w kan. 28 $\$ 1 \mathrm{KKKW}$ jako dziedzictwo liturgiczne, teologiczne, duchowe i dyscyplinarne wyodrębnione przez kulturę i okoliczności historyczne

24 Por. J. Prader, Il matrimonio in Oriente e in Occidente, dz. cyt., s. 226: „D'altronde é da considerasi valido il matrimonio benedetto da diacono latino per benedire il matrimonio di cattolici orientali". 
narodów, wyrażające się w przeżywaniu wiary, właściwym dla każdego Kościoła sui iuris ${ }^{25}$. Taka definicja nie występuje w legislacji zachodniej.

Badając terminologię Kodeksu z 1983 r. komentatorzy podkreślają, iż pojęcie „ritus” funkcjonujące w tym zbiorze nie jest jednoznaczne. Analizując ten problem Natale Loda wymieniła trzy jego znaczenia, jakimi są: znaczenie liturgiczne, znaczenie w sensie „coetus fidelium” oraz znaczenie prawno-eklezjologiczne ${ }^{26}$. Nawiązując do tego wątku Elmar Güthoff zwrócił uwagę, iż w kodyfikacji tej w większości norm pojęcie „ryt” utożsamia się z Kościołem. Niemniej jednak, jak zauważył niemiecki kanonista, w zbiorze tym pojawia się również termin „Ecclesia ritualis sui iuris” (kan. $111 \mathrm{KPK})^{27}$, wprowadzony do obiegu już w trakcie prac kodyfikacyjnych w celu zapewnienia koherentności $\mathrm{z}$ terminologią funkcjonującą w prawie wschodnim ${ }^{28}$.

W art. 7 DCIC posłużono się pojęciem rytu w znaczeniu prawno-ustrojowym, gdyż ustawodawca operuje terminem „Kościół łaciński"29. Zapis tego artykułu koresponduje ze zmianami terminologicznymi wprowadzonymi w art. 1-2 DCIC, te zaś są koherentne z terminologią występującą w kan. 29-30 KKKW.

25 Por. U. NowickA, Obrządek, w: G. Leszczyński (red.), Wielka Encyklopedia Prawa, t. 2, Warszawa 2014, s. 138.

26 Por. N. Loda, Rito, w: J. Otaduy, A. Viana, J. Sedano (red.) Diccionario general de Derecho Canónico, t. 7, Pamplona 2012, s. 43.

27 Por. E. Güthoff, Rito, w: S. Haering, H. Schmitz (red.), Diccionario enciclopédico de Derecho Canónico, (tłum. H. Bernet), Barcelona 2008, s. 743.

28 Por. „Communicationes” 12 (1980), s. 72. Szerzej na ten temat zob. J. García Martín, Le norme generali del Codex Iuris Canonici, Roma 1999, s. 378. Valesio de Paolis i Andrea D’Auria twierdzą, iż wprowadzenie w Kodeksie z 1983 r. terminu „Ecclesia ritualis sui iuris” jest logiczną konsekwencją zapisu kan. $372 \$ 2$ KPK stwarzającego możliwość utworzenia Kościoła partykularnego nie na bazie terytorium, ale na bazie rytu. Por. V. De Paolis, A. D’Auria, Le norme generali di Diritto Canonico. Commento al Codice di Diritto Canonico, Roma 2008, s. 305.

29 Szerzej na ten temat zob. R. SobAŃski, Komentarz do kan. 1 KPK, w: J. KRUkowski, R. Sobański, Komentarz do Kodeksu Prawa Kanonicznego, t. 1, Poznań 2003, s. 46. 


\section{Nowa regulacja w strukturze kan. 1116 KPK (art. 10 DCIC)}

W art. 10 DCIC prawodawca dołączył do kan. 1116 KPK regulującego sprawę zawierania małżeństwa w formie nadzwyczajnej dołączył $\$ 3$ stanowiąc, iż ordynariusz miejsca może udzielić jakiemukolwiek kapłanowi katolickiemu władzy do błogosławienia małżeństwa wiernych Kościołów wschodnich niepozostających w pełnej wspólnocie z Kościołem katolickim, którzy dobrowolnie o to proszą, jeśli nic nie stoi na przeszkodzie ważności i godziwości zawieranego związku.

Komentując tę regulację na początku trzeba stwierdzić, iż jest ona nowa. Zawarta w niej dyspozycja pozostaje w pewnym związku z dyspozycją kan. $844 \$ 3$ KPK zgodnie z którym „Szafarze katoliccy godziwie udzielają sakramentu pokuty, Eucharystii i namaszczenia chorych członkom Kościołów Wschodnich niemających pełnej wspólnoty z Kościołem katolickim, gdy sami o nie sami o nie proszą [...]”. Bezpośrednim źródłem tego kanonu są treści zawarte w n. 14 soborowego „Dekretu o ekumenizmie”, w którym stwierdzono, iż „Kościoły Wschodu i Zachodu przez wiele wieków kroczyły swoimi własnymi drogami złączone jednak wspólnotą wiary i życia sakramentalnego" (DE 14). Prawdę tę uwydatniono jeszcze wyraźniej w art. 122 Dyrektorium Ekumenicznego ${ }^{30}$ w następującym twierdzeniu: „Między Kościołem katolickim a Kościołami wschodnimi istnieje zawsze bardzo ścisła łączność w dziedzinie wiary" ${ }^{31}$.

W końcowym zdaniu art. 10 DCIC ustawodawca obliguje kapłana błogosławiącego do powiadomienia o tym fakcie kompetentną władzę zainteresowanego niekatolika. Wydaje się, iż zobowiązanie, o którym mowa implicite, wynika z dyspozycji art. 125 Dyrektorium Ekumenicznego, w którym podkreślono, iż przy udzielaniu sakramentów należy unikać wszelkiego prozelityzmu.

\footnotetext{
30 Por. Papieska Rada do Spraw Jedności Chrześcijan, Dyrektorium w sprawie realizacji zasad i norm dotyczacych ekumenizmu-25.03.1993, „Communio” 14 (1994) nr. 2, s. 57.

31 Por. K. LÜDICKE, Heiligungsamt: Sakramente in allgemeinem, w: K. LÜDICKE (red.), Münsterischer Kommentar zum Codex Iuris Canonici, t. 4, Essen 1985, ad. 844, 1.
} 


\section{Zakończenie}

Z przeprowadzonych analiz wynika, iż za modyfikacją zapisów kilku kanonów dokonaną w DCIC przemawiały różne racje. Pierwszą z nich, jak zaznaczono już we „Wprowadzeniu” papieskiego dokumentu, jest harmonizacja norm funkcjonujących w legislacji zachodniej z tymi, które występują w legislacji wschodniej. Oprócz tego, nie bez znaczenia pozostał również kolejny powód uwydatniony we „Wprowadzeniu” DCIC związany z faktem, iż katolicy wschodni są zobowiązani do zachowania swojej dyscypliny wszędzie tam, gdzie się znajdują (kan. $40 \$ 3 \mathrm{KKKW})^{32}$.

Konkludując należy stwierdzić, iż uściślenie zawarte w art. 11 DCIC, w myśl którego małżeństwo katolika z wiernym wschodnim może być $\mathrm{w}$ warunkach zwyczajnych celebrowane wyłącznie przy czynnym współudziale kapłana kładzie kres doktrynalnym dyskusjom w kwestii możliwości błogosławienia takiego związku przez diakona.

Z kolei nieznaczna, aczkolwiek istotna modyfikacja treści kan. 1109 KPK (art. 7 DIC) wiąże się z niejednoznacznością terminu „ritus” funkcjonującego w legislacji zachodniej. Uwydatnienie znaczenia prawno-ustrojowego pojęcia „Kościół łaciński” z jednej strony koresponduje ze zmianami terminologicznymi wprowadzonymi $\mathrm{w}$ art. 1-2 DCIC, z drugiej zaś jest spójne z terminologią występującą w kan. 29-30 KKKW.

Wreszcie, nowa hipoteza wprowadzona w art. 10 DCIC dotycząca formy nadzwyczajnej zawarcia małżeństwa rozszerza zakres uprawnień katolickiego ordynariusza miejsca. Prawodawca, biorąc pod uwagę względy ekumeniczne, pragnie wyjść naprzeciw potrzebom duchowym wschodnich akatolików znajdujących się w szczególnych warunkach. Poszerzył on zatem zakres możliwości w posłudze względem akatolickich wiernych, którzy znaleźli się w sytuacji nadzwyczajnej.

\footnotetext{
32 Por. J. Prader, Aspetti specifici nel Codice Orientale rispetto al Codice Latino in materia matrimoniale, Quaderni della Mendola, t. 3, Milano 1996, s. 37.
} 


\section{The Changes in the Text of Canons in the Area of Material Marital Law Based on Motu Proprio „De concordia inter Codices”}

\section{Summary}

The major focus of attention of the author of the article was the question of the changes in the text of canons in the area of material marital law based on motu proprio „De concordia inter Codices” issued on 31st May 2016 by Pope Francis.

The conclusions of the author drawn from his thorough analysis of the content of this papal document are as follows: firstly, the clarification included in art. 11 DCIC puts an end to doctrinal discussions concerning the possibility of a deacon assisting in giving marriage to Eastern faithfuls; secondly, the modification of the content of can. 1109 CIC (art. 7 DCIC) results from the ambiguity of the term "ritus" functioning in Western legislation - the author believes that accentuating the legal-institutional meaning of the notion corresponds with terminological changes introduced in art. 1-2 DCIC, while, on the other hand, it is consistent with the terminology included in canons 29-30 CCEO; thirdly, the new hypothesis included in art. 10 DCIC related to the extraordinary form of entering into marriage widens the range of competence of a Catholic ordinary of a place. This is because the legislator, taking into account ecumenistic considerations, wishes to meet the spiritual needs of Eastern non-Catholics who found themselves in an unusual situation. 